\title{
管理型海面廃棄物処分場における 基礎杭打設が底面遮水基盤に与える影響
}

\author{
平尾 隆行1・森脇 武夫 2 ・菊池 喜昭 ${ }^{3}$ \\ 1正会員 中電技術コンサルタント株式会社＼cjkstart都市整備部（テ734-8510 広島市南区出汐二丁目3-30） \\ E-mail: hirao@cecnet.co.jp \\ 2正会員 呉工業高等専門学校教授 環境都市工学分野（二737-8506 広島県呉市阿賀南二丁目2-11） \\ E-mail: moriwaki@kure-nct.ac.jp \\ 3正会員＼cjkstart東京理科大学教授＼cjkstart理工学部土木工学科（テ278-8510 千葉県野田市山崎2641） \\ E-mail: kikuchi_y@rs.tus.ac.jp
}

管理型海面廃棄物処分場跡地の高度利用にあたっては，廃棄物層と底面遮水層（粘性土層）を貫通して 支持地盤まで基礎杭を打設することが必要となる場合がある。この杭打設に伴い廃棄物や保有水が遮水層 内一連れ込まれ, 結果的に処分場の外部へ拡散, 浸出することが懸念され, この懸念が処分場跡地の有効 利用を阻害している一因となっている。本研究においては，このような杭打設中の連れ込み問題に対して， その影響を明らかにし，対策方法や適用範囲等について実験的に検討を行った。検討の結果，杭打設に伴 う粘性土地盤の攪乱を防止することで連れ込みの影響を低減できることが判明し，杭内部の廃棄物を掘削 しながら打設する中堀り工法や，既成杭の先端部を鋭角化する工法，或いは杭周面への膨潤性遮水材料を 塗布する工法等の適用性が示唆された。

Key Words : controlled waste landfill, clay liner, water interception, driven pile, disturbance of the clay

\section{1. はじめに}

\section{(1) 研究の背景}

我が国の大規模な廃棄物最終処分場は，廃棄物を大量 に排出する大都市圏の近傍で，かつ我が国の狭险な土地 事情から海面の沖合部に立地することが多い.これらの 海面処分場は，埋め立てが終了してその役目を果たした 後には，広大な土地が完成する一方，周辺の港湾区域が 拡大することによって，その土地は非常に重要な位置を 占めるようになる。この場合，廃棄物処分場の跡地は非 常に利用価値の高い土地となり，港湾関連用地のみなら ず，交通用地や商業用地，更には居住用地としても有効 活用することが望まれる，このことは，国土が狭く沿岸 部に平野の少ない我が国にあって，新規の埋め立てや開 発が環境側面から制約を受ける現状においては，非常に 有益なことであると考えられる.

このような廃棄物処分場は，土砂処分場等の一般の埋 立地とは状況が異なり，土地利用にあたっては廃棄物処 分場特有の配慮が必要となる。まず，海面処分場の基礎 地盤は，一般的には埋め立てられた廃棄物とその下方の
未改良の在来粘性土地盤で構成されており，特に橋梁や マンション等の大型構造物を支持する基礎地盤としては 強度的に適切でないことが多い.また，粘性土地盤は大 半が正規圧密地盤であり，跡地利用においては残留沈下 も問題となる。つまり，跡地利用にあたっては構造物基 礎としての支持力確保と沈下防止を同時に実現する必要 がある。

一般的には，これらの対策として地盤改良（深層混合 処理工法やサンドコンパクションパイル工法等）や杭基 礎（既成杭，場所打ち杭等）の適用が考えられるが，前 者の地盤改良工法については，埋め立て廃棄物とその下 方の粘性土層を同時に撹拌改良することから，廃棄物と 処分場内の保有水を処分場外へ拡散させることは避けら れず，廃衰物地盤上から粘性土層も含めて地盤改良する ことは現時点では現実的に困難な工法である.

後者の杭基礎工法については，地盤改良工法ほどでは ないものの，図-1のように廃棄物層と粘性土層を連続し て杭が貫通してしまうことから，埋め立て廃棄物等を処 分場外へ拡散させることが懸念される．特に，この粘性 土層は，廃棄物処分場の底面遮水工として利用されて 


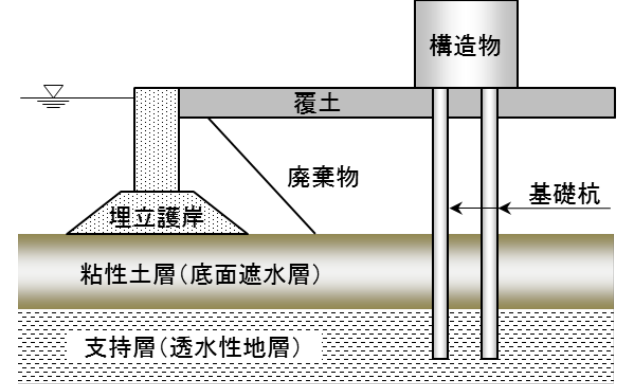

図-1 海面廃棄物処分場への杭打設イメージ

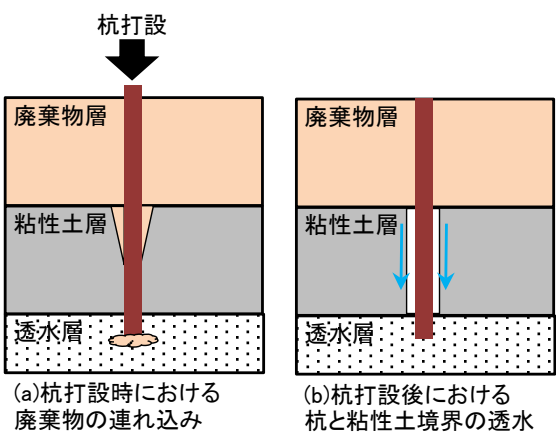

図-2 杭打設時における課題
いることも多く，この場合将来にわたる跡地利用におい ても遮水機能を健全に保持し続ける必要がある.

このような䀣念から，処分場跡地は現在のところ緑地 や公園，ゴルフ場，駐車場等，地盤改良や杭基礎が不要 な比較的低レベルでの施設利用，場合によっては跡地そ のものが未利用に留まっているのが現状であり，処分場 跡地の高度利用を可能とするための工法の開発が望まれ ているところである.

本研究においては，処分場跡地の高度利用を可能とす る地盤改良工法や杭基礎工法等のうち，廃棄物の拡散や 保有水の漏えい等の周辺環境一与える影響が比較的小さ く, 技術開発の可能性がある杭基礎工法に着目寸るもの とする.

\section{（2）処分場での基礎杭打設における課題}

処分場跡地一基礎杭を打設する際に生じる課題として は, 大きく以下に示寸二つの項目が想定される.

\section{a) 杭打設時の課題}

処分場へ杭を打設する際の課題の一つとして，図-2(a) に示すように，杭の打設に伴う廃棄物の連れ込2等に代 表される比較的短期間で生じる問題がある.

処分場の原地盤面から直接基礎杭を打設すると，杭の 先端や側面に廃棄物や保有水が付着寸ることで, これら が遮水層下方の透水層まで連れ込まれ，透水層を通じて 周辺環境へ影響を及ぼすことが䀣念される.

\section{b) 杭打設後の課題}

課題の二つ目としては，図-2(b)に示すように，杭打設 後に杭と周辺地盤との境界面を通じて保有水が流れる等, 杭を打設した後に比較的長期間にわたって生じる問題が ある。

\section{(3) 既往の研究}

海面廃棄物処分場において, 廃棄物層と底面遮水層 （在来粘性土層）を貫通して基礎杭を打設することを想 定し，以下のような研究がおこなわれている.

菊池・橋爪 $\left.{ }^{2}\right)$ は, 杭周辺の透水性の変化について検討
するため，圧密リング内に杭を設置した状態で透水試験 を実施している，その結果，過圧密状態で杭周辺に隙間 を作った場合には境界面を相当量の通水が確認されるが, 正規圧密領域まで載荷すると, 空隙は閉塞し透水量も問 題にならない程度まで回復することを確認している。

また，冨士ら゙は，剛壁型透水試験装置を用いて，試 験装置の直径より小さい供試体で透水試験を実施し，杭 と粘性土との隙間の影響について検討している. その結 果，正規圧密領域では隙間は完全に閉塞し，粘性土の 遮水性も構造基準を十分に満たすことを確認している.

以上の実験的研究は, 前項(2) b)の杭打設後の課題に 対するひとつの見解を示しているものと考えられる.

一方，(2）a）杭打設時の課題に対しては, 福田ら ${ }^{4}$ が 粘性土モデル地盤上に砂を敷き，この中に模型杭を打設 することで, 杭の先端形状や打設工法と砂の連れ込久深 度について実験的に検討している.この結果, 先端閉塞 型の杭では杭径程度の深度まで砂が連れ込まれることや, 中堀工法では砂の連れ込みが無いことなどを確認してい る.

この実験は，杭打設に伴う砂の連れ込みに着目したも ので，保有水の連れ込みやその深度，或いは杭打設に伴 う遮水層の乱れの影響等に関しては未だ不明な点が残さ れている.

\section{(4) 本研究において対象とする現象と目的}

処分場での基礎杭打設には先に示した通り，大きく二 つの課題があるが，本研究においては，「杭打設時にお ける課題」に着目し，杭打設中の比較的短時間に生じる 問題について，その影響を明らかにし，対策方法や適用 範囲等について一定の方向性を見出すことを目的に，実 験的に検討を行うものである.

なお，本研究においては，底面遮水工として在来粘性 土層を持つ管理型海面最終処分場を想定している.この ため, 特に断りの無い限り, 単に処分場とはこの海面処 分場を指すものとする. 


\section{2. 実験概要}

処分場跡地において廃棄物層や粘性土層を貫通して基 礎杭を打設する際に連れ込まれる廃棄物や保有水につい て，室内模型実験を実施することにより検討する.

実験においては，実現場において主に既成杭（鋼管杭 やコンクリート杭）を各種工法（打撃工法や中堀り工 法）で打設することを想定し，その中で廃棄物の連れ込 みに影響を与えると想定される以下のパラメータに着目 する.

- 廃棄物の種類 : 固体 (廃棄物), 液体（保有水)

・杭の先端形状 : 開端，閉端，ペンシル（先尖）型

・施工中のブレ : 杭周面での粘性土の乱れや杭と粘性 土との間の空隙の有無

- 連れ込み防止対策 : 膨閏性遮水材料の塗布の有無 なお，中堀り工法のような杭の内部を掘削しながら杭 を建て込む工法については，今回の室内実験装置では構 造的に実施が困難であるため，杭を直接打設する打撃工 法を基本に実験を行い，その結果から中堀り工法の適用 性について考察を加えるものとする.

実験ケース等の詳細は後述するが，ここでは本研究に おいて行った実験のうち，用いた試料や供試体作製方法， 分析方法等，共通する項目について述べる.

\section{(1) モデル地盤材料}

粘性土層（遮水層）をモデル化する地盤材料として， 沿岸部に自然に堆積した在来粘性土を用いた。

実験を行う工程上，表-1に示寸二か所から採取したが， いずれも港湾の航路浚渫で発生した浚渫粘性土である。 これらは採取する場所は異なるものの，いずれも瀬戸内 海産で比較的物理特性が類似したものとなっている.

\section{（2）モデル地盤作製方法}

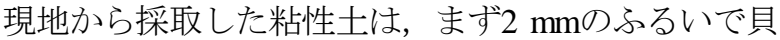
殼や粗粒分を取り除いた．その後，後述するトレーサー

（砂）の連れ込み量を測定するために250umふるいを通

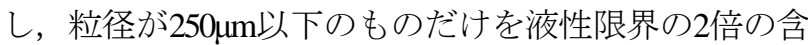
水比で練返して調製する.

その後，脱気を行い，図-3に示寸圧密容器に投入した 後，24時間サイクルで0 kPa（自重），5kPa，10 kPa，20

表-1＼cjkstart地盤材料諸元

\begin{tabular}{|c|c|c|}
\hline 採取場所 & 広島港 & 徳山下松港 \\
\hline 土粒子密度 $\rho_{S}\left(\mathrm{~g} / \mathrm{cm}^{3}\right)$ & 2.621 & 2.773 \\
\hline 液性限界 $w_{L}(\%)$ & 98.2 & 95.9 \\
\hline 塑性限界 $w_{P}(\%)$ & 40.6 & 47.9 \\
\hline 塑性指数 $I_{P}$ & 57.6 & 48.0 \\
\hline
\end{tabular}

$\mathrm{kPa} ， 50 \mathrm{kPa}$ の圧密圧力のもと，両面排水で圧密を行う. 最終荷重（50 kPa）においては，3TE法により決まる圧 密終了時間まで圧密を行い，その後各種実験を行う。

なお，この最終圧密荷重（50 kPa）については，実際 の海面処分場において，層厚10 $\mathrm{m}$ 程度の廃棄物の土被り 圧に相当する．これは，廃棄物が埋め立てられた後の底 面遮水層（粘性土層）の表層付近に該当する.

また，モデル地盤は50 kPaで圧密後の地盤高が8～12 cmとなるように作製するが，これは実地盤で用いられ

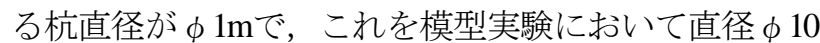
$\mathrm{mm}$ の模型杭で再現する場合には，層厚が8〜 $12 \mathrm{~m} の$ 地盤 に相当する.

\section{(3) トレーサー（砂）}

廃棄物の固体部分を模す材料として，珪砂を用いるこ ととする. 本来廃萧物は多種多様なもので構成され， 様々な性状を示し，どのようにモデル化しても全ての実 問題を表現できる方法は無いと考えられる，そこで，実 際の廃棄物が砂のような単純な粒状体ではないことは明 らかであるが，実験条件が統一でき，細粒の焼却灰に粒 径が近い珪砂6号を用いることで，杭周辺の廃棄物の連 れ込み状況を比較的容易に確認できると考えた。

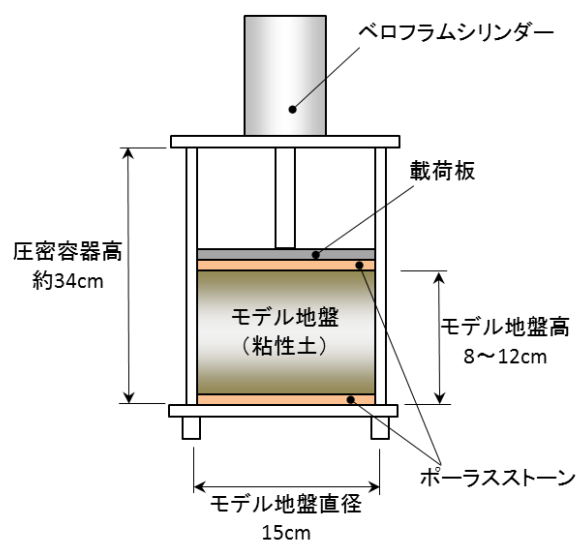

図-3 圧密容器概要図

表-2 砂（珪砂6号）の諸元

\begin{tabular}{|c|c|c|c|}
\hline \multicolumn{2}{|c|}{ 粒度分布 } & \multicolumn{2}{|c|}{ 化学組成 } \\
\hline $\begin{array}{c}\text { ふるるい目 } \\
(\mu \mathrm{m})\end{array}$ & $\begin{array}{c}\text { ふるい } \\
(\%)\end{array}$ & 成分 & $(\%)$ \\
\hline 700 & 0 & Ig-loss & 1.1 \\
\hline 590 & 0 & $\mathrm{SiO}_{2}$ & 96.2 \\
\hline 420 & 22 & $\mathrm{AL}_{2} \mathrm{O}_{3}$ & 1.4 \\
\hline 300 & 34 & $\mathrm{Fe}_{2} \mathrm{O}_{3}$ & 0.7 \\
\hline 210 & 26 & $\mathrm{CaO}$ & 0.1 \\
\hline 150 & 12 & $\mathrm{MgO}$ & 0.2 \\
\hline 105 & 5 & & \\
\hline 75 & 1 & & \\
\hline 75 以下 & 0 & & \\
\hline 計 & 100 & & 99.7 \\
\hline
\end{tabular}


珪砂の物性を表-2に示す．後の実験において粘性土層 内への砂の連れ込多状況を確認するため, 粘性土と珪砂 をふるいにより分離する必要があることから，珪砂は

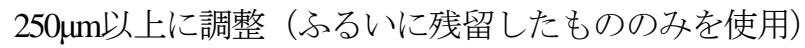
する．また，粘性土地盤上に珪砂を敷設した際に珪砂が 吸水することを防止するため，実験前に2.(4)で後述する 臭化カリウム溶液で飽和させておく.

\section{（4）トレーサー (溶液)}

廃棄物層内の保有水を模す材料として，粘性土の土粒 子への吸着や微生物分解がほとんど無く，安定した陰イ オンである臭化物イオンを用いる．実験においては臭化 カリウム溶液（KBr）として臭化物濃度5,000 mg/Lに調整 して使用する.

\section{(5) トレーサー（溶液）の分析方法}

粘性土層内に連れ込まれた臭化物イオンは，下記の方 法により分析し，濃度を算定する.

供試体から採取した粘性土試料（2 g 程度）をスクリ

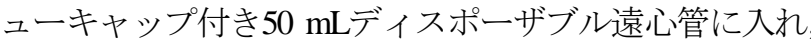
直径 $\phi 1 \mathrm{~mm}$ のガラスビーズ10個程度と精製水20 mLを加 え，振とう機（振とう幅 $4 \mathrm{~cm}, 200 \mathrm{rpm}$ ）で2時間振とう 抽出する. 静置後7,000 rpmで20分間遠心分離し, 上澄を $20 \mathrm{~mL}$ のシリンジに付けた $0.45 \mu \mathrm{m}$ のディスポーザブルフ イルタでろ過する。このろ液を精製水で適宜10２0倍に 希釈後, イオンクロマトグラフィーにより臭化物イオン 濃度を測定する。

表-3 イオンクロマトグラフィーの諸元

\begin{tabular}{|c|c|}
\hline 装置 & Dionex DX-320 \\
\hline 分離カラム & $\mathrm{AS} 17(4 \mathrm{~mm} \times 250 \mathrm{~mm})+\mathrm{AG} 17(4 \mathrm{~mm} \times 50 \mathrm{~mm})$ \\
\hline カラム温度 & $35^{\circ} \mathrm{C}$ \\
\hline SRS電流 & $200 \mathrm{~mA}$ \\
\hline 溶離液流量 & $2 \mathrm{~mL} / \mathrm{min}$ \\
\hline
\end{tabular}

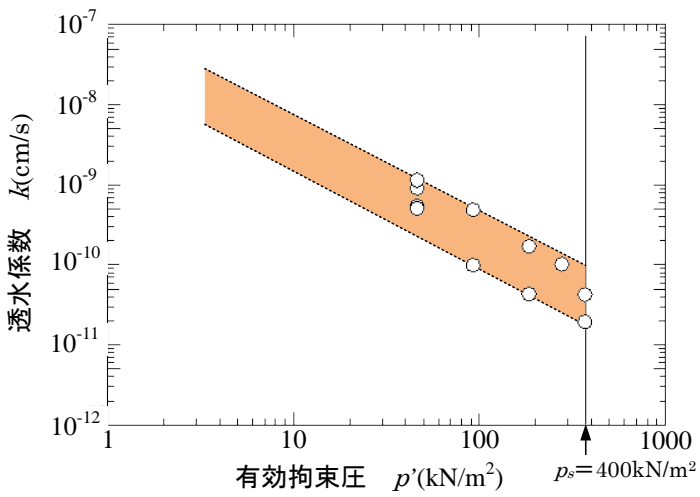

図-4 有効拘束圧と透水係数の関係 ${ }^{10)}$

\section{（6）膨潤性遮水材料}

杭打設に伴う廃棄物の連込み抑制対策の一つとして, 杭周辺に膨潤性の遮水材を塗布する手法の有効性につい て検討する．用いる遮水材は，通常は固体であるが吸水 すると膨潤してゲル状になるもので，特殊バインダー樹 脂と吸水性ポリマーを有機溶剤に分散させたものである。

この膨潤性遮水材料の透水性を図-4に示す。透水係数 の值は拘束圧にも依存するが最大でも $k=1 \times 10^{-8} \mathrm{~cm} / \mathrm{s}$ と かなり小さく，遮水材として十分な機能がある10). なお， 図中の $p_{s}=400 \mathrm{kN} / \mathrm{m}^{2}$ は，膨潤性遮水材の膨潤量がゼロ (膨潤しない) となる拘束圧である.

\section{3. 杭打設時の課題に対する検討}

(1) 保有水の連れ込みに対して ${ }^{6}$

a) 実験概要

ここでは，杭打設に伴う粘性土層内への保有水の連れ 込み現象について検討する.

本実験においては広島港で採取した粘性土を用い, 2.(2)で述べたとおり，圧密容器で粘性土のモデル地盤を 作製する．作製後は，杭を打設するため， ベロフラムシ リンダーと載荷板を取り外す。この状態では粘性土地盤 は過圧密状態にあるため，粘性土地盤が攪乱されクラッ クが生じやすく，また粘性土と杭との付着性が低いため 杭と粘性土との間に隙間が生じやすいものとなっている。 このため，本実験条件は，杭打設に伴う連れ込みの影響 が大きい条件となっているものと考えられる.

その後，図-5に示すように，圧密容器内に2.(4)で調整 した臭化物イオン溶液を投入し，粘性土地盤上に保有水 を水深約 $2 \mathrm{~cm}$ で貯留した状態とし，モデル地盤中央に模 型杭を3〜 $4 \mathrm{~cm} /$ 分の比較的ゆっくりとした速度で鉛直に 押し込む. 模型杭はアルミ製の中実，先端は平坦閉塞と し，杭外径 $\phi$ は $5 \mathrm{~mm}, 10 \mathrm{~mm}, 15 \mathrm{~mm}$ の三種類とする.

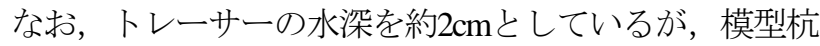
の打設前後で静水圧は変化しないため, トレーサーの水 深は保有水の連れ込多に大きく影響しないと考えている.

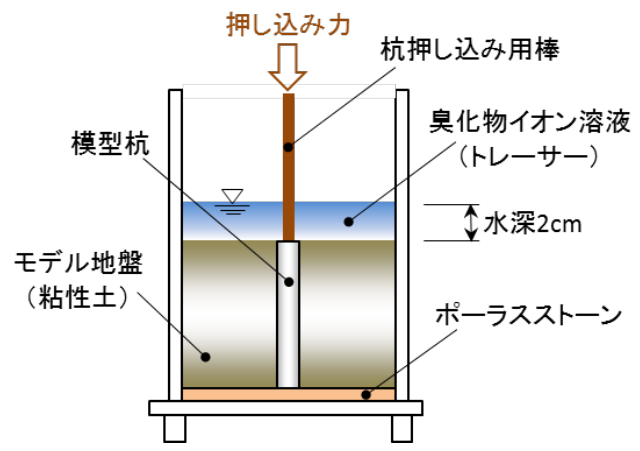

図-5 模型杭打設状況図 


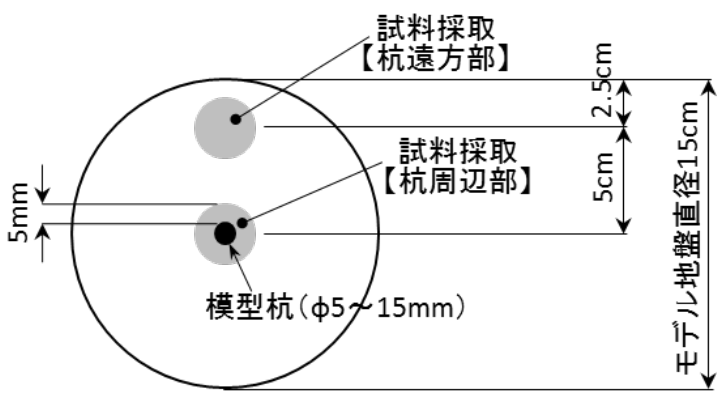

図-6 試料採取位置平面図

杭がモデル地盤底部まで達したら即座に圧密容器を解 体して試料を取り出す．容器から取り出した試料は，杭 周辺5 mm幅部分と，連れ込みの影響が無いと考えられ る杭から $5 \mathrm{~cm}$ 龪方の部分を，それぞれ深度方向に $1 \mathrm{cmず}$ つ， $5 \mathrm{~g}$ 程度採取し，2.(5)に示した方法により臭化物イオ ン濃度を測定する。試料採取位置を図-6に示す。

\section{b) 実験結果}

得られた結果は，海水中に含まれる臭化物イオンの影 響を除外するよう，下式に示す相対濃度 $\left(C / C_{0}\right)$ として整 理するとともに，この相対濃度の杭周辺と遠方との濃度 差 $\Delta\left(C / C_{0}\right)$ として整理する.

$$
\begin{aligned}
& \left(C / C_{0}\right)=\left(C_{M}-C_{1}\right) /\left(C_{2}-C_{1}\right) \\
& \Delta\left(C / C_{0}\right)=\left(C / C_{0}\right)_{N}-\left(C / C_{0}\right)_{F}
\end{aligned}
$$

$$
\text { ここに, }
$$

$\left(C / C_{0}\right)$ : 臭化物イオンの相対濃度 $(\mathrm{mg} / \mathrm{L})$

$C_{M}:$ 濃度の実測值 $(\mathrm{mg} / \mathrm{L})$

$C_{1}:$ 初期間隙水中の濃度 $(\mathrm{mg} / \mathrm{L})$

$C_{2}:$ 供給液の濃度 $(\fallingdotseq 5,000 \mathrm{mg} / \mathrm{L})$

$\Delta\left(C / C_{0}\right):$ 杭近傍と遠方との濃度差 $(\mathrm{mg} / \mathrm{L})$

$\left(C / C_{0}\right)_{N}:$ 杭近傍の相対濃度 $(\mathrm{mg} / \mathrm{L})$

$\left(C / C_{0}\right)_{F}:$ 杭力ら遠方の相対濃度 $(\mathrm{mg} / \mathrm{L})$

粘性土地盤内における臭化物イオンの相対濃度の深度 分布（杭径 $\phi 15 \mathrm{~mm}$ の場合）を図-7に，杭近傍と遠方と の濃度差の深度分布を図-8に示す。

図-7を見ると，モデル地盤の地表面付近で杭の打設の 有無に関わらず高い濃度が確認できるが，これはトレー サーがモデル地盤の上面と接していたためである.

この影響を除外し，杭の打設による影響のみを見るた め, 濃度差で整理した図-8を見ると, 明らかにモデル地 盤表層付近（深度約 2 cm以浅）において濃度増加が確認 できる. この原因は，杭打設中の比較的早い段階に発生 したモデル地盤表面のクラック（図-9）の内部にトレー サ一が浸入したためと考えられる。しかし，この影響深 度は限定的であり，深度約 $2 \mathrm{~cm}$ 以深においてはトレーサ 一の連れ込み現象はほとんど認められない.

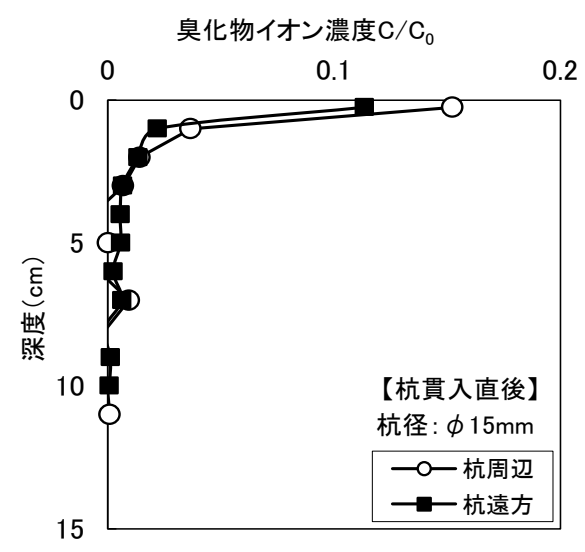

図-7 濃度の深度分布

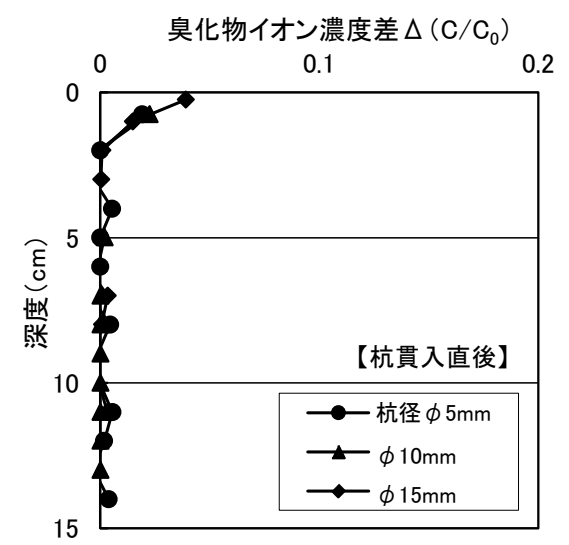

図-8 濃度差の深度分布

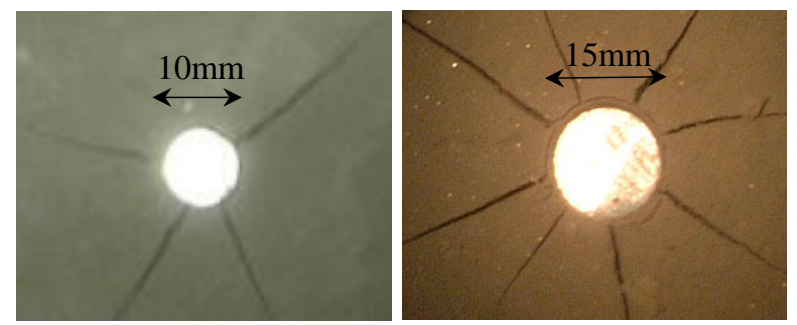

図-9＼cjkstart杭打設直後に生じたモデル地盤地表面のクラック

この杭打設に伴いモデル地盤表面に生じるクラックに ついて，実験中に観察された様子を図-9に示す。写真は モデル地盤の地表面を上部から見下ろしたもので，写真 中央の杭を中心に放射状にクラックが伸びていることが 確認できる.このクラックは杭打設中の比較的初期に生 じたもので，杭打設の後半は，モデル地盤表面に発生し たクラックの平面的な広がりは確認できていない.

このクラックの発生状況について，図-10に示す円弧 すべり解析（修正フェレニウス法による全応力解析）に より，基礎の根入 $D_{f}$ （杭の貫入量に相当）をパラメータ として，安全率 $F_{s} か ゙ 1.0$ となる荷重強度 $p$ と，その時のす ベり面（破壊面）の範囲 $L$ につて検討した。本解析は 二次元解析であり，実験で確認された三次元的な挙動を 
厳密には再現できないが，杭の根入とクラックの発生状 況を定性的に確認できるものと考えている.

検討結果を図-11に示す。この図は，横軸に根入れと 基礎幅の比 $D / B$, 縦軸にすべり範囲と基礎幅の比 $L^{\prime} / B$,

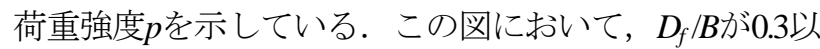
下の場合（杭の根入れが浅い場合に相当），すべり面の 範囲 $L ’ は$ 荷重強度の増加とともに拡大傾向にあるが， 0.3 を超えると，す心゙り面範囲，荷重強度ともほぼ一定值を 示す（変化が無くなる）。

このことから，図-12のイメージ図に示すように，杭 打設の初期においては杭の押し込み力によって生じる地 盤中の破壊面が地表面まで達寸ることでクラックが生じ るが，一定の深度以深においては破壞面が地表まで達す ることはないものと考えられる.

以上のことから，杭打設に当たっては粘性土層（遮水 層）の攪乱や乱れが少ない工法の選定が必要であること を示唆するものと考えられる。

一方，本実験は過圧密状態（モデル地盤に上載圧が無 い状態）となっており，実際の処分場においては粘性土 層（遮水層）の上には廃棄物層が存在し，この自重によ る拘束圧が作用するため，このような極端な状態にはな らないものと想定される.

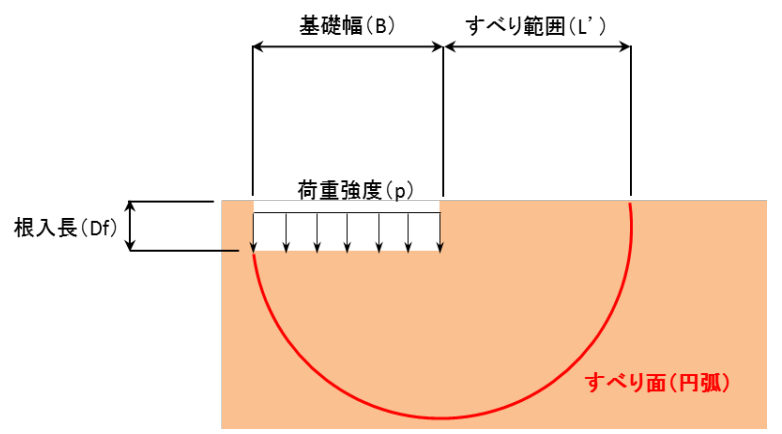

図-10 円弧すべり計算概要図

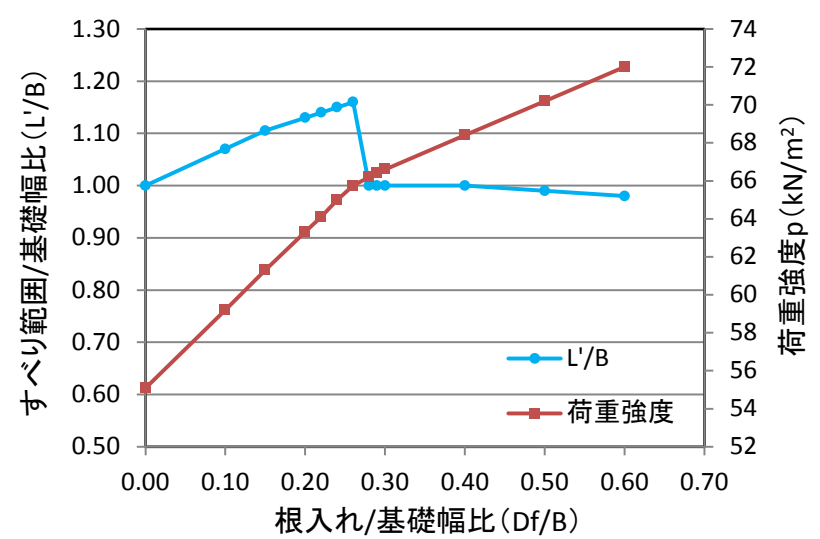

図-11 根入とすべり範囲

\section{（2）廃棄物の連れ込みに対する杭先端形状の影響入,8)}

ここでは，杭打設に伴う粘性土地盤内一の廃㶳物（固 形物）の連れ込み現象について検討寸る. 廃棄物地盤の 中に直接杭を打設する場合，杭先端や周辺に廃棄物が付 着することが想定される．特に，杭先端部はその形状に より，連れ込々現象が大きく異なると想定されることか ら，ここでは杭の先端形状による影響を検討する.

なお，廃棄物には多種多椂なものがあるが，ここでは， 2.(3)で述べたとおり粒状体を主体とした廃棄物を対象と して，廃棄物を珪砂で模擬する.

\section{a) 実験概要}

基本的な実験手順は前節3.(1)と同様であり，徳山下松 港で採取した粘性土を用いて，2.(2)で述べたとおり粘性 土モデル地盤を作製する. その後, 圧密容器内に2.(3)で 調整した飽和珪砂を層厚 $10 \mathrm{~cm}$ で敷設し，モデル地盤上 に廃棄物が存在する状態を模した上で，モデル地盤中央 に模型杭を押し込む.

杭打設完了後，即座に試料を取り出し，杭周辺 $1 \mathrm{~cm}$ 幅

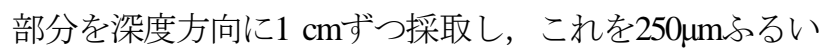
により粘性土と連れ込まれた砂とに分離して, 炉乾燥後 の砂の質量を測定する（図-13）.

模型杭についてはアルミ製の杭径 $\phi 10 \mathrm{~mm}$ ，杭先端形 状を平坦とし, 閉端杭と開端杭（開口径 $\phi 8 \mathrm{~mm}$ ) を比 較する．なお，開端杭については，同じ条件で2回モデ ル地盤を作成して実験を行った。

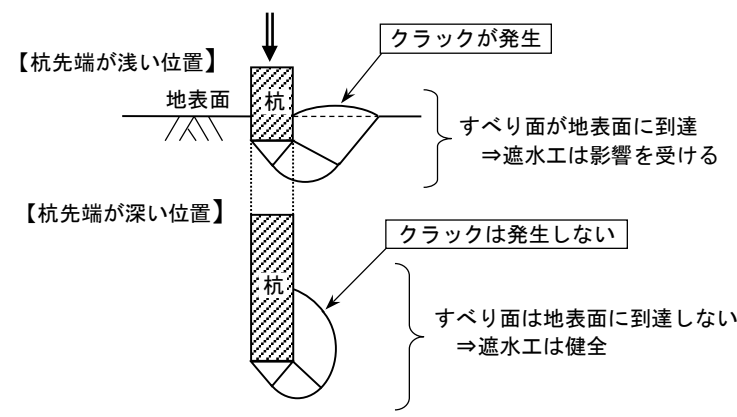

図-12 杭打設に伴う地盤の破壊形態 (イメージ)

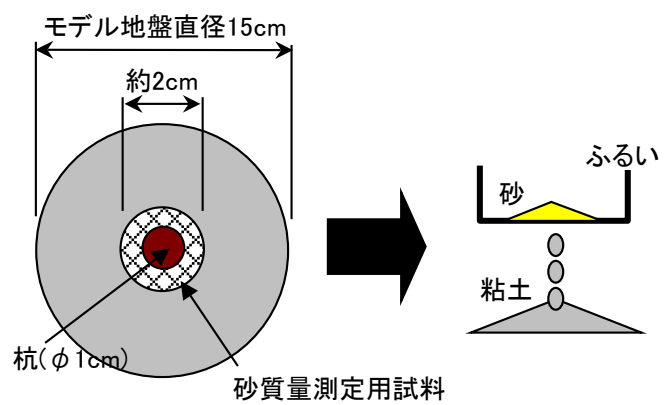

図-13 試料採取位置平面図 
一方，杭先端形状は図-14に示すように閉端ペンシル （先尖）型として，先端角度 $\theta$ を度（平坦），30度，45 度，60度，75度に変化させ，特に杭先端部に連れ込まれ る砂の質量について比較する.

なお，いずれの杭も，模型杭の先端部がモデル地盤の 粘性土層を貫通して下部ポーラスストーンに接する（杭 の貫入が困難となる）まで打設する.

\section{b) 実験結果}

得られた結果は，モデル地盤内に連れ込まれた砂の質 量を深度分布として整理する. 閉端杭と開端杭の比較図 を図-15に示す。これによると，モデル地盤の地表付近 に連れ込まれた砂量は，開端杭より閉端杭の方が多く

（約2倍），これに調和するように，それ以深の砂の連 れ込み深度も，開端杭が深度3 cmに留まるのに対して， 閉端杭は深度 $6 \mathrm{~cm}$ まで及んでいる．これは，杭が砂層内 を貫入する際，開端杭は杭内部に一定量の砂を取り込み, 杭先端の主働くさび部の形成が十分でなく，杭先端の連 れ込み量も小さかったためと考えられる.

杭先端形状の比較については，モデル地盤底部（厚2 cm部）に連れ込まれた砂量について整理し，図-16に示 す.これによると，明らかに杭先端の鋭角化に伴い，砂 の連れ込み量が低下していることが確認できる。これは 図-17に示すように杭先端の鋭角化により，杭先端部に
砂による主働くさびが形成され難くなり，モデル地盤底 部への連れ込み量も減少したものと考えられる.

\section{（3）杭打設による粘性土地盤の攪乱の影響7,8)}

ここでは，杭打設中に想定される杭のブレ等に起因す る粘性土地盤への連れ込みの影響について検討する．杭 の打設工法には，中堀り圧入やプレボーリング埋め込み 工法，打撃工法等多くの種類があるが，工法毎に打設中 の周辺地盤の乱れを定量的に評価することが困難である ため，実験においては杭の打設中に杭に強制変位を与え て，杭と周辺地盤との間に隙間を生じさせることで便宜 的に杭打設に伴う周辺地盤の乱れの影響として検討する。

\section{a) 実験概要}

基本的な実験手順は前節3.(2)と同様であり，徳山下松 港産の粘性土を用いて作製した粘性土モデル地盤上に飽 和珪砂を敷設し，直径 $\phi 10 \mathrm{~mm} の$ 閉端模型杭を押し込む 杭打設中においては，図-18に示すように，杭を粘性 土層内に $2 \mathrm{~cm}$ 貫入する毎に，粘性土表層における水平変 位が片側 $3 \mathrm{~mm}$ となるように杭頭に強制的に8万向に水平 変位を与える.これにより，杭と周辺地盤と間に隙間が 生じ，この隙間の中に珪砂が落ち込むことになる.

なお，水平変位3 $\mathrm{mm}$ は杭径 $10 \mathrm{~mm}$ の3割，トレーサー である砂の最小粒径250 $\mu \mathrm{m} の 12$ 倍であり，実際の施工で

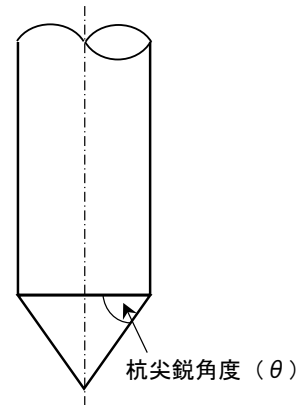

図-14 杭先端部形状と尖鋭角度 $(\theta)$

砂の質量(g)

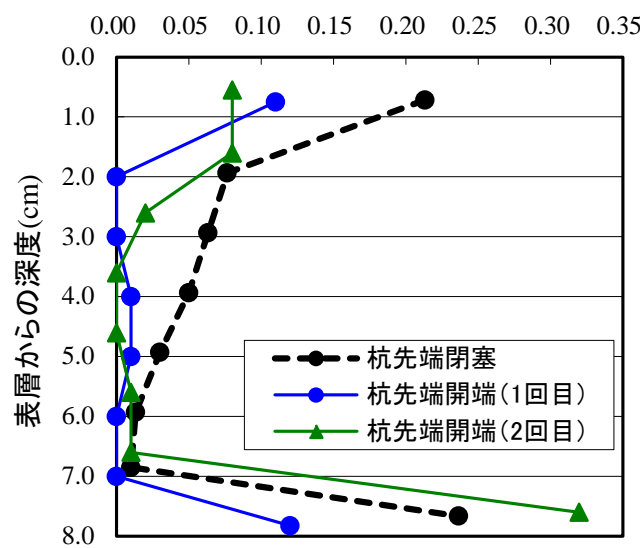

図-15＼cjkstart連れ込多砂量の深度分布（杭先端形状の影響）

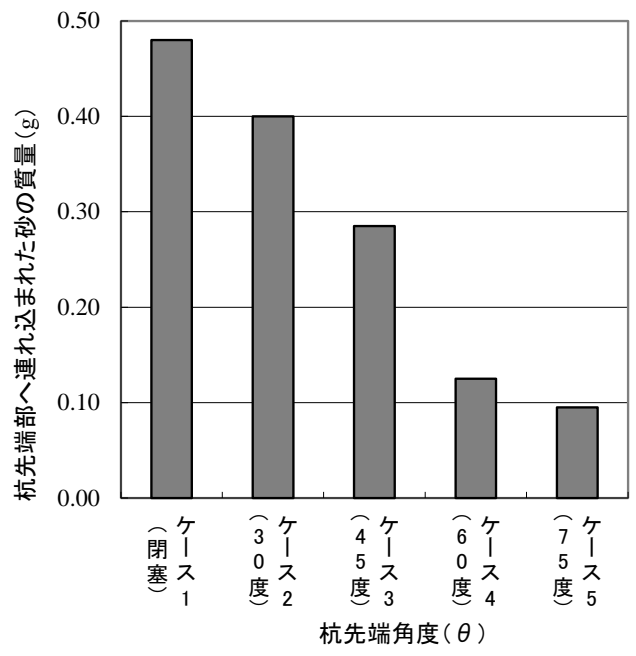

図-16 モデル地盤底部での連れ込み砂量

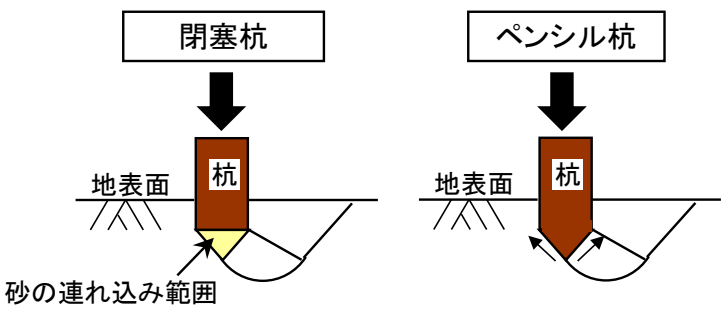

図-17＼cjkstart杭先端部での連れ込み現象 
は余り起こり難い大きさであると考えられるが，杭と地 盤との間にできた隙間に廃棄物が入り込む傾向を調べる ために設定したものである.

また，打設する模型杭は，モデル地盤に比べて岡性が 非常に高く，杭頭に水平変位を与えても杭本体は曲げ変 形しない．このため，周辺地盤は杭の傾斜に応じた隙間 が生じることとなり，加えて過圧密地盤であるため，一 度形成された隙間は元に戻り難いことから，考えられる 限りで最も安全側の実験条件とした.

\section{b) 実験結果}

前項と同様に，モデル地盤内に連れ込まれた砂の質量 の深度分布として整理する。図-19によれば，杭頭に変 位を与えた場合，モデル地盤内に連れ込まれた砂量が多 くなり，特に，深度3〜 $4 \mathrm{~cm}$ 以浅で顕著である.

このモデル地盤内に連れ込まれた砂の総量は， $V_{s}=0.9$ $\sim 1.2 \mathrm{~cm}^{3}$ (飽和密度 $\rho_{\text {sat }}=1.7 \mathrm{~g} / \mathrm{cm}^{3}$ で換算, 間隙比 $e=1.5$ 程 度）であり，これは，杭の打設深度 $2 \mathrm{~cm}$ における杭周辺 の空隙体積 $V_{v}=1.1 \mathrm{~cm}^{3}$ (円環錐体積) とほぼ等しい. な お，杭の打設深度8cm（杭全長）における杭周辺の空隙 体積は $V_{v}^{\prime}=4.5 \mathrm{~cm}^{3}$ である. このことは，杭頭に強制変位 を与えても，杭底先端部を支点とした変形挙動とはなら ず，変位の中立点が杭の中間部にある挙動となり，杭周

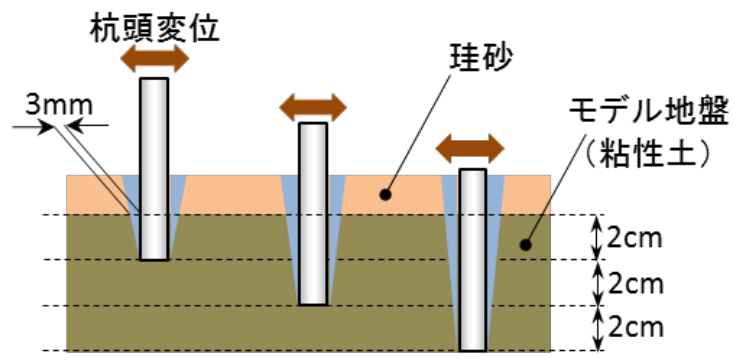

図-18＼cjkstart杭の打設と水平変位の付与

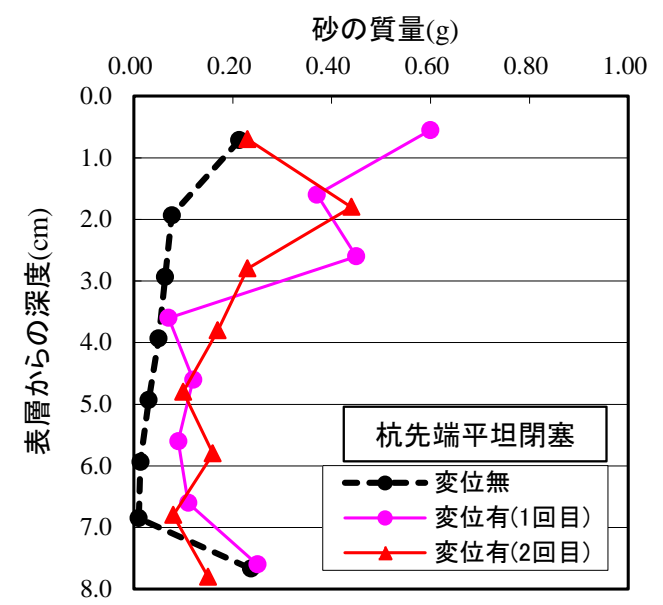

図-19＼cjkstart連れ込み砂量の深度分布（杭变位の影響）
辺の空隙も比較的浅い部分に限定されることが想定され る.一方で，杭底先端部を支点とした変形挙動が生じる ものとすると，杭周辺の空隙体積 $\left(V_{v}^{\prime}=4.5 \mathrm{~cm}^{3}\right)$ に対し て，連れ込み砂量 $\left(V_{s}=\right.$ 約 $\left.1.1 \mathrm{~cm}^{3}\right)$ は1/4程度である。こ の要因として，飽和砂の粒子同士の摩擦やアーチ作用等 により砂粒子が空隙に落ち込み難かったこと等が考えら れる.

いずれにしても，杭と粘性土との隙間寸法と廃棄物の 粒径, 及び杭の変形挙動等が連れ込み量に密接に関連す ることが推察される.

\section{（4）膨潤性遮水材料の効果 ${ }^{9,10)}$}

これまでの実験的検討により，廃棄物層に打撃工法の ような杭を直接打設する工法では，その影響の程度に大 小はあるものの，何らかの影響があることが判明した。 廃棄物が連れ込まれる原因のひとつとして，杭と廃肓物 との摩擦が考えられるが，ここではこの摩擦力を低減さ せることを目的とした「膨閏性遮水材料」を杭に塗布す ることで，廃棄物の連込み防止に対する効果を検証する. この膨潤性遮水材料は，杭と廃棄物との間で生じる大き なせん断変形の下で材料内ですべりが生じ，これによっ て遮水性を維持した状態でも摩擦力の低減を可能とする ものである。

\section{a) 実験概要}

用いた膨潤性遮水材料は2.(5)に示したもので，杭周面 に0.1〜0.2 mm厚で塗布し, 乾燥させたものを使用する. 基本的な実験手順は前項までと同様で，前項までの実験 ケースに追加する形で実施し，膨閏性遮水材料の効果の みを検証する。

なお，この膨閏性遮水材料は，杭に塗布して乾燥した 状態では固体状を示し，杭の打設中も剥がれることはな いが，水と反応して膨閏するまでに若干の時間を要する. そこで，本実験においては，杭が砂層（廃棄物層）を貫 通した段階で2時間程度放置し吸水膨張させ，その後粘 性土層内に押し込むこととする.

\section{b) 実験結果}

まず，杭先端が平坦閉塞杭で，杭径 $\phi 10 \mathrm{~mm}$, 杭頭変 位を与えたケースで，膨潤性遮水材料の有無の比較を図 -20に示す.

これによれば，遮水材が塗布されていないケースでは 表層から深部にかけて砂が連れ込まれていることが確認 されるが，遮水材を塗布したケースでは表層付近で比較 的大きな連れ込みが確認されるものの，深度 $2 \mathrm{~cm}$ 以深で は連れ込み量が大幅に低減されている。これは，遮水材 が膨張することで杭周辺の隙間を埋めること，及び遮水 材の摩擦低減効果により連れ込み量が抑制されているも のと考えられる.

ただし，杭先端部については，先端形状が平坦閉塞と 
砂の質量 $\left(\mathrm{g} / \mathrm{cm}^{3}\right)$

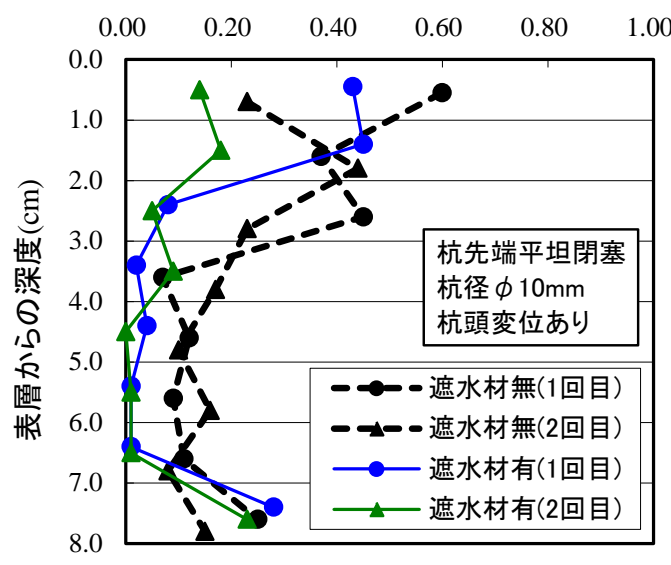

図-20 連れ込み砂量の深度分布（遮水材の効果）

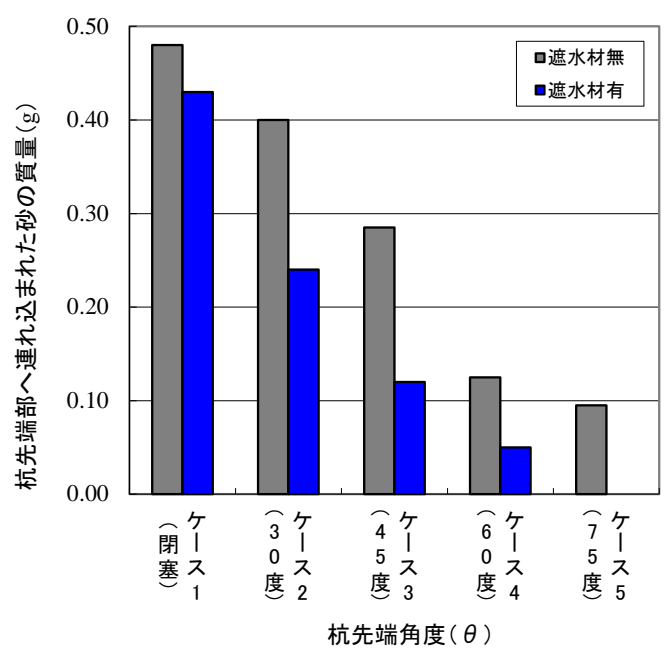

図-21

モデル地盤底部での連れ込み砂量（遮水材の効果）

いうこともあり，連れ込み量に有意差は見られない。

次に，杭先端形状を閉端ペンシル型として，尖鋭角度 $\theta$ を0度（平坦），30度，45度，60度，75度に変化させた 場合について, 膨潤性遮水材料の有無による比較実験結 果を図-21に示す。なお，膨潤性遮水材料は尖鋭部にも 塗布している.

いずれのケースにおいても膨閏性遮水材料の効果が表 れており，特に尖鋭角度が75度のケースにおいては，砂 の連れ込みが全く確認されなかった。これは尖鋭部への 膨潤性遮水材料の塗布が，連れ込久量の低減に非常に効 果的であることを示しているものと考えられる.

この膨潤性遮水材料を塗布した杭は，図-22に示寸よ うに砂層 (廃棄物層) の中で土中の水分（保有水）を吸 収し，膨閏することでゲル状になる，そして，粘性土地 盤へ杭を打設する際には，このゲル状の樹脂が剥離して 砂層内に留まることから, 杭と砂の摩擦が低減され, 結 果的に砂の連れ込みが低減されるものと考えられる.

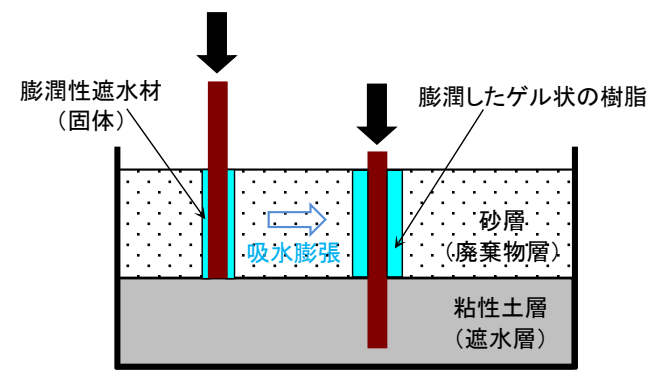

図-22 膨閏性遮水材料の連れ込み防止効果 (イメージ)

また，杭の打設時に変形を与えた場合でも，杭と地盤 との隙間をゲル状の樹脂が埋めることで，隙間に砂粒子 が入り込むことを防止し，連れ込みが低減されるものと 考えられる.

\section{4. 結論}

管理型海面廃衰物処分場において，廃棄物による埋め 立てが終了した後の跡地を高度に有効利用しようとする 際には，重量構造物の構築等，廃棄物層と底面遮水層々 なる粘性土層を貫通して基礎杭を打設することが必要と なる場合が考えられる.

この基礎杭打設において問題となる「杭打設時におけ る課題」と「杭打設後の課題」のうち，本研究において は，前者の杭打設時における課題に着目し，杭打設中の 比較的短時間に生じる問題について，その影響を明らか にし，対策方法や適用範囲等について一定の方向性を見 出すことを目的に，実験的に検討を行った．以下にその 主要な結論を述べる.

\section{（1） 保有水の連れ込み}

過圧密地盤（粘性土地盤上に上載圧の無い状態）にお いては，杭の打設に伴い粘性土地盤表面付近にクラック が生じ，その攪乱深度付近までは保有水（実験ではトレ 一サー溶液）が連れ込まれる，杭打設に当たっては可能 な限り粘性土地盤を乱さない工法の選定が必要である.

\section{（2）粘性土地盤の攪乱の影響}

杭打設中に杭頭に強制変位を与えた場合，杭と地盤と の間に形成された隙間に廃棄物（実験では砂）が入り込 むため，廃棄物が遮水層の深部まで連れ込まれる可能性 がある．杭打設に当たっては可能な限り粘性土地盤を乱 さない工法の選定が必要である.

\section{(3) 杭先端形状の影響}

杭先端の形状が平坦閉塞杭に比較して，開端杭やペン シル杭は廃棄物の連れ込み量が少ないことが確認された。 このことから，既成杭の打撃工法にあってはペンシル杭 
の適用性が示唆されるとともに，開端杭についても打撃 工法のみならず，杭内部の廃棄物を除去しながら杭を打 設する中堀り工法の適用性が高いものと想定される.

\section{（4）膨潤性遮水材料の効果}

膨潤性遮水材料を塗布した杭を廃棄物層内で膨潤させ た後に粘性土地盤内へ打設することで，杭外周面に付着 する廃棄物の粘性土地盤内一の連れ込みが低減できるこ とが確認された。このことから，廃棄物の連込み防止対 策のひとつとして今後効果が期待できる.

\section{5. あとがき}

本研究は，中電技術コンサルタント株式会社と広島大 学大学院, 吳工業高等専門学校環境都市工学科, 及び東 京理科大学が実施した共同研究の成果をとりまとめたも のである.

ここでは，管理型海面廃棄物処分場における杭打設が 底面遮水基盤（粘性土地盤）に与える影響について，主 として杭打設時において生じる課題に着目し，実験的に 研究を行った成果をとりまとめた.

今後は，杭打設後において長期的に生じる遮水層への 影響評価を行うとともに，これらを踏まえて将来的な実 施工に向けて技術的課題を解決し, 海面処分場跡地への 杭打設工法を確立することにより，処分場の高度利用を 進めることが期待される.

\section{参考文献}

1) 管理型廃棄物埋立護岸 設計・施工・管理マニュアル （改訂版），（財）港湾空間高度化環境研究センタ 一, 134 p., 2008.
2) 菊池喜昭，橋爪秀夫：杭周辺地盤の透水性に関する 室内透水試験, 第 6 回環境地盤工学シンポジウム発 表論文集，pp. 217-224, 2005.

3）富士暁之, 勝見武, 嘉門雅史, 乾徹：改良型透水試 験装置を用いた鋼管杭一粘土境界面における透水量 の評価, 第 7 回環境地盤工学シンポジウム発表論文 集，pp. 281-286, 2007.

4) 福田賢二郎, 上田正樹, 杉原広晃, 渡部要一：海面 管理型廃棄物処分場の遮水基盤への基礎杭打設の影 響, 第 39 回地盤工学研究発表会, pp. 2267-2268, 2004.

5) 菊池喜昭, 森脇武夫, 勝見武, 平尾隆行, 蔦川徹, 服部晃，岡本功一，山田耕一，佐々木広輝：管理型 海面廃棄物処分場に打設する基礎杭が底面遮水基盤 に与える影響，港湾空港技術研究所資料，No. 1252, 2012.

6) 平尾隆行, 下所諭, 福原和顕, 蔦川徹, 森脇武夫, 小松登志子 : 海面管理型廃棄物処分場の底面遮水工 に及ぼす基礎杭打設の影響, 第 38 回地盤工学研究発 表会, pp. 1212-1214, 2003.

7）平尾隆行, 眞田一磨, 森脇武夫, 岡本功一：基礎杭 打設による海面処分場の底面遮水工に与える影響 （短期的現象）の考察，第 44 回地盤工学研究発表会, pp. 1907-1908, 2009.

8）蔦川徹，森脇武夫，岡本拓，服部晃，岡本功一，渡 辺修士，平尾隆行，眞田一磨：基礎杭打設時の表面 処理が海面処分場の底面遮水工に与える影響（短期 的影響），第 20 回廃棄物資源循環学会研究発表会, pp. 403-404, 2009.

9) 蔦川徹, 森脇武夫, 服部晃, 岡本功一, 平尾隆行, 眞田一磨: 基礎杭打設による海面処分場の底面遮水 工に与える短期的影響（杭先端部）の考察，第 21 回 廃棄物資源循環学会研究発表会, pp. 483-484, 2010.

10) 岡本功一，森脇武夫，菊池喜昭，蔦川徹，服部晃， 平尾隆行 : 管理型海面処分場へ打設する杭一の塗布 材としての膨潤性止水材の効果の検証，第 67 回土木 学会年次学術講演会講演概要集, III-047, 2012.

(2016. 8. 17 受付)

\section{EFFECTS OF FOUNDATION PILE DRIVING ON THE BARRIER CLAY LAYER IN COASTAL WASTE LANDFILL SITE ON THE SEA}

\section{Takayuki HIRAO, Takeo MORIWAKI and Yoshiaki KIKUCHI}

In the advanced use of coastal waste landfill site on the sea, there is a case in which installation of foundation piles through waste layer and the barrier clay layer is necessary to support heavy structures. Associated with this pile driving, there is a concern about that wastes and retained water are taken into the barrier clay layer, and diffuse to the outside. This concern is one of the causes to inhibit the advanced use of the landfill site. In the present study, against these problems, a series of experiments was carried out to clarify the effects of leakage of wastes and polluted water into clay layer during pile driving, and to examine the effect and application range of the measures. As the result of the investigation, it was found that the prevention of the disturbance of the clay layer due to the pile driving is important to reduce the influence of leakage of wastes and polluted water. The methods of driving while drilling inside the pile, of using the pile with an acute angle of end point, and of applying a swellable cut-off of water material to the pile surface were suggested as the measures. 